\title{
Attendance at the Five Daily Congregational Prayers, Imams and Their Communities in the Jurisprudential Debates during the Ottoman Age of Sunnitization
}

\author{
H. Evren Sünnetçioğlu
}

On 25 Receb 1000/7 May 1592, imam Receb and his congregation from the Hasan Ağa neighborhood of Üsküdar went to the court. They notified the judge of Üsküdar that a certain resident by the name of Hasan does not attend the masjid for prayers, nor does he pray at all. Upon listening, the judge decided to record Hasan into the court register. ${ }^{1}$ It is not clear whether this entry served as a prelude for an investigation against Hasan. The judge seemed to be cautious, as evident in his choice to qualify the allegation as haber (Ar. khabar), which signals that he treated it as information that can be either true (sidq) or false (kidhb). ${ }^{2}$ However, Hasan's reputation was now formally jeopardized because his social infamy for disregarding the five daily prayers entered the official record. If the allegations had been proven as true, Hasan could have been

1 'Zikr olunan imâm ve cemâ'at bâ'isü'l-hurûf Hasan nâm kimesneyinamaza gelmez ve bî-namazdır deyu haberverdikleri kayd olundu. Şuhûdül-hâl:es-Sâbikūn." See İstanbul kadısicilleri Üsküdar Mahkemesi 84 numaralı sicil 247. For the name of the imam and the neighborhood, see the preceding entry on the same page. It is worth emphasizing that the neighbors of Hasan did not just claim that he neglects the five daily congregational prayers (namaza gelmez; lit. "he does not come to prayer"). They also denounced Hasan for not observing the five daily prayers at all (ve bi-namazdır; i.e. "and he does not pray"), implying that he does not perform his prayers even in the privacy of his home. On the boundary between "public" and "private" in the Ottoman neighborhoods during the tenth/sixteenth century, see Yllmaz, xvi. yüzyll Osmanlı toplumunda 92-110. On similar examples of denouncement from other places of the Empire, see Ergenç, Osmanlı şehrindeki "mahalle"nin 74; Kıvrım, Osmanlı Mahallesinde 233; Yllmaz, XVI. yüzyıl Osmanlı toplumunda 96-97.

2 Jurisprudentially speaking, haber (Ar. khabar) can be true (șidq) or false (kidhb) as opposed to proof (al-ḥujja huwā al-khabar al-șidq). See Mollā Hüsrev, Durar al-ḥukkām ii, 27o. On the question of proof standards in the proceedings of criminal cases, see Johansen, Zum Prozessrecht der 'Uqūbāt 421-433. 
liable for a punishment. At the very least, both the complaint by the congregation and the judge's decision to record Hasan indicates the growing emphasis on Ottoman Muslims' attendance at the five daily congregational prayers that was increasingly perceptible by the mid-tenth/sixteenth century.

This paper focuses on the debates among the leading Hanafi jurists that informed this growing sensitivity to and moral surveillance surrounding the performance of the congregational prayers, as well as the judge's decision to record Hasan's alleged misconduct. Based on differences of opinion (ikhtiläf) among some of the earliest authorities of the Hanafi school (madhhab), the debates specifically revolved around two major questions that long predated the Ottoman era: the normative value of the five daily congregational prayers and the ability and qualifications of imams to lead the prayer. I explore how Hanafi jurists of Rum (Anatolia and the Balkans) received and intervened into this debate, arguing that their particular interpretation provided the Ottoman authorities with a legal and moral idiom to discipline their male Muslim subjects by enforcing the congregational performance of the five daily prayers. This is famously reflected in the decree promulgated by Sultan Süleymān in 944/ 1537-1538, which obliged each and every Muslim-populated village in the empire to have a designated place of prayer (masjid) in order to ensure the observance of the five daily prayers in congregation throughout the sultan's domains.

In what follows, I examine how Ottoman jurists received the aforementioned debates and engaged with them before and after the promulgation of this imperial decree, suggesting that the decree was a product of negotiation between the jurists and the sultan on the latter's role in the everyday piety of his subjects and the enforcement of the divine law within the Ottoman domains. I argue that by the turn of the tenth/sixteenth century the jurists and the sultan had arrived at a consensus on the normative value of the five daily congregational prayers by rendering the sultan responsible for promoting masjid attendance among his male Muslim subjects. Thus, the Ottoman reception of this age-old but virtually unexplored jurisprudential debate became central to the processes of confession-building and imperial consolidation from the ninth/fifteenth to the eleventh/seventeenth centuries.

In the second part of the paper, I demonstrate how the jurists navigated the debates on the ritual and moral duties of imams that had a bearing on attendance itself, with a particular attention to the question of whether prayer behind a sinful imam is permissible. This question came into sharper focus due to the growing expectations of moral leadership and communal surveillance in the mid-tenth/sixteenth century. I demonstrate that the Ottoman jurists navigated through the differences of opinion both within and beyond the Hanafi school to define their own orthodoxy on this matter, treading carefully to contain dissenting voices from Muslim congregations across the empire. 


\section{The Decree of $944 / 1537-1538$ in the Context of Ottoman "Sunnitization"}

The imperial decree of 944/1537-1538 ordering the construction of masjids in Muslim-populated villages to enforce the regular performance of the five daily prayers in congregation has been at the center of the discussions on Ottoman "Sunnitization." ${ }^{3}$ Although the original text of the decree is still missing, our knowledge of its content comes from a fatwa issued by the chief jurist (şeyhü'lislām) Ebū's-su'ūd:

Question: If some Muslims have no masjid at all in their villages, and if the people do not perform the prayers in congregation, is it necessary for the judge of the law to force them to build a masjid and to inflict discretionary punishment?

Answer: Yes. The governors of the protected domains had been sent a noble decree in 944 in order to force the people of such villages to build a masjid and to make them attend the congregational prayers. It is necessary to abide by what the decree requires. ${ }^{4}$

As the fatwa makes it clear, the decree was issued in 944/1537-1538 by Sultan Süleymān (r. 926-974/1520-1566) before Ebū's-su'ūd was appointed chief jurist (952-982/1545-1574). It concerned the Muslim peasants who neither observed the five daily congregational prayers, nor did they even have a masjid. In order to deal with this matter, Süleymān stipulated punitive measures. The governors and judges of the empire had to force the villages in question to construct a masjid. Also, they were authorized to inflict discretionary punishment ( $t a$ z $i r$ ) in order to prevent nonattendance at prayers. These punitive measures were confined to Muslim men since Muslim women had by then been banished from

3 For the discussion of the term "Sunnitization," see Terzioğlu, How to conceptualize 301-338.

4 "Mes’ele: Ba'̇̇ Müslümānlar, ḳaryelerinde aṣlā mescid olmayub ahālīsī cemā'atle namāz ḳılmasalar hạkimü'ş-şer' mezbūrlara cebr ile mescid binā etdürüb namāz ḳlmakdan ihmāl edenleri tązir lāzım olur mu? El-cevāb: Olur. Öyle olan ḳurānın ahālīsine cebrile mescid binā etdürüb șalāta müdāvemet etdürmek içūn vülāt-ı Memālik-i Maḥmiye'ye sene-i erba'̄n ve tis'ami'e tārīhinde mü̉ekked ahkām-ı şerīfe vārid olmuşdur. Mūcebince 'amel olunmak lāzımdır. Ketebehu Ebū's-su'ūd 'ufiya 'anhu." Ebū Su'ūd, Zur Anwendung 24. This is my transliteration of the fatwa from Ebū's-su'ūd's Ma'rū paper when discussing the fatwa because it includes Ebū's-su'ūd's annotations, which are omitted from the more recent edition by P. Düzenli (Ebussuûd, Ma'rûzât). I use the latter edition when I discuss the preface of the Ma'rū more manuscript copies than Horster. 
attending the congregational prayers. ${ }^{5}$ The decree, Ebū's-su'ūd affirms, is still valid: "it is necessary to abide by what the decree requires."

In recent years, historians have pointed to this decree as an example of how Ottoman authorities' understanding of Sunni Islam changed toward the middle of the tenth/sixteenth century. The primary purpose of the decree was to enforce the congregational performance of the five daily prayers in the villages since it took issue with the lack of masjids in the villages and not the Friday mosques in cities and towns. As a rule, the jurists of the Hanafi school, and by extension the Ottoman Rumi Hanafi jurists, excluded Friday mosques from villages, since they held that the Friday noon prayer was valid only in urban regions (misr jāmi'; misr), not in the countryside. ${ }^{6}$ However, apart from the construction boom of masjids across the empire, the decree was also followed by the proliferation of Friday mosques in cities and towns. ${ }^{7}$ Gülru Necipoğlu has suggested that this general emphasis on the places of prayer in congregation was due to the religious climate at the time, which was informed by the Ottoman authorities' attempt to draw clear distinctions with the Shi' ite Safavid Empire, its principal ideological rival. ${ }^{8}$ Indeed, the very legitimacy of holding the Friday prayer was then under debate among the Twelver Shi'ite scholars. ${ }^{9}$ As such, the decree was part of broader policies aiming to establish the markers of Ottoman Sunni orthodoxy as the empire sought to internally consolidate and demarcate boundaries with its imperial rivals both to the east (the Safavids) and to the west (the Habsburgs). ${ }^{10}$

Derin Terzioğlu has pushed the discussion further in a historiographical essay that challenges the view of Sunnitization as a mere political reaction provoked by the rise of the Shi'ite Safavid Empire (r. 9o6-1134/1501-1722). Instead, she emphasized the need to study Ottoman Sunnitization in its own right as part of the history of Sunni Islam with an eye to continuities and ruptures between the religious policies of the pre-Ottoman and Ottoman eras. ${ }^{11}$ Taking

See Katz, The "corruption of the times" 171-185; Reinhart, When women went to mosques $116-128$.

6 Johansen, The all-embracing town, esp. 144; Calder, Friday prayer 35-36; Holmes Katz, Prayer 130-131; Necipoğlu, The age of Sinan $5^{6}$.

Necipoğlu, The age of Sinan 48; see also Terzioğlu, How to conceptualize 314. On the numbers of masjids and Friday mosques constructed in Rumeli by the 1530s, see Grigor Boykov's article in this volume.

$8 \quad$ Necipoğlu, The age of Sinan 47-58.

9 Stewart, Polemics and patronage 425-457.

10 Necipoğlu, Süleyman the Magnificent 401-427; Krstić, Contested conversions 75-97; Greene, The Edinburgh history $57-86$, especially 59.

Terzioğlu, How to conceptualize 305, 313, 315, 318-319. 
this historical approach is significant from the standpoint of the decree under discussion: while the decree of 944/1537-1538 was unprecedented in scope, it was not unique in kind - a similar order was issued in 717/1317 under the Mamluk sultanate that ordered Nusayris in the Tripoli district to construct masjids in their villages. ${ }^{12}$

In the context of Ottoman history, Terzioglu situates the decree at the intersection of architectural, administrative, and legal historiography with the following question in mind: how did the Ottoman legal and political authorities conceive of the neighborhoods and villages along with religious, penal, and fiscal rights and liabilities? ${ }^{13}$ Although the decree of 944/1537-1538 heightened the significance of mosques and masjids in the neighborhoods and villages, Terzioğlu notes that evidence from the reigns of Mehmed II (r. 848-850/14441446; 855-886/1451-1481) and Bāyezīd II (r. 886-917/1481-1512) indicates that enforcing the five daily congregational prayers was a religious policy already before the onset of the rivalry between the Sunni Ottoman and Shi'ite Safavid Empires. At this juncture, Terzioğlu puts forth several "agents of Sunnitization," who had greater responsibilities in the neighborhood and village contexts (such as the imam, muezzin, and judge) or were new figures (such as the prayer enforcer, i.e., namāzcl) in the history of Sunni Islam, as worthy of further investigation. While Ottoman authorities particularly authorized namāzcıs, imams, and muezzins to monitor male Muslims to make sure they attended the daily prayers, they also coupled these new measures with "empowering the judge" and "mobilizing the local populace to provide community surveillance" in order to compensate for the limits of the state in terms of its access and control over the daily life of neighborhoods and villages. To this end, Terzioğlu invites comparisons with relatively more institutional, parish-based mechanisms of social disciplining in early modern Europe. ${ }^{14}$

Building on Terzioğlu's insights on how to conceptualize Ottoman Sunnitization, Tijana Krstić demonstrated that Ottoman catechisms ( $i l m-i h a \bar{a} l)$ as well underscored the significance of attendance at the congregational prayers in their discussions of what it entailed to be a Sunni Muslim. Written during the reign of Sultan Süleymān by Hanafi authors with and without ties to the state, within and beyond the circles of madrasa-trained scholars, these widely circulated catechisms tailored the medieval attributes of "the people of the Sunna and the Community" (ehl-i sünnet ve'l-cemā'at, Ar. ahl al-sunna wa-l-jamā'a) to

\footnotetext{
12 Tsugitaka, State and rural society 171-172.

13 Terzioğlu, How to conceptualize $313-315$.

14 Ibid. $313-315,322$.
} 
highlight the differences between Sunnis and Shi'ites on the matters of creed and piety. ${ }^{15}$ As such, they espoused the discourse implicit in Süleymān's decree through emphasizing the importance of performing the five daily prayers with the congregation (Lütfî Pasha) or praying behind imams regardless of whether they are sinful or not ('Abdu'r-raḥmān bin Yūsuf Aḳsarāyī, Birgivī Meḥmed, and Lüțì Pasha).

Given the central place that the question of attending the five daily congregational prayers at the local masjids occupied in the religious policies and catechisms, it is all the more pressing to understand how the debates of the leading Ottoman jurists informed this concern. In the following section, I will demonstrate that the decree of 944/1537-1538 was not an arbitrary decision. Rather, it was a product of a consensus reached among the jurists on an ageold debate as to the normative value of the five daily congregational prayers. By doing so, I will shed light on the moral and legal registers that jurists invoked in arguing for the duty of adult male Muslims to observe and the duty of the sultan to enforce attendance at the masjids.

Traces of a Jurisprudential Debate: Normative Value of the Five Daily Congregational Prayers and the Question of Attendance

In his Ghunyat al-mutamallī, written as a handbook for students, Ibrāhīm alḤalabì (d. 956/1549), a Hanafi scholar educated in Mamluk Aleppo, Damascus, and Cairo who migrated to Ottoman Istanbul around 9o6/150o and became a prominent jurist there, offers a curious prelude to his discussion on a centuriesold jurisprudential debate regarding the normative value of the five daily congregational prayers. ${ }^{16}$ Starting with a succinct survey of the different opinions held by various jurists from the formative period of the Sunni schools of law, al-Halabì introduces the question in a way that encapsulates the central point of contention among the Ottoman Hanafi jurists of Rum that underpins Sul$\tan$ Süleymān's decree: Are the adult male Muslims under a duty to observe the five daily congregational prayers? If so, under what circumstances should the sultan implement the penal sanctions to ensure that they do not abandon the prayers? The jurists debated this issue throughout the ninth/fifteenth and the early tenth/sixteenth century, effectively arriving at a consensus by

15 See Krstić, State and religion 65-91.

16 On Ibrāhīm al-Ḥalabī, see Has, $A$ study. 
the time the decree was issued in 944/1537-1538: "In al-Așl, Muhammad [b. alḤasan al-Shaybānī (d. 189/805)] said: 'Know that prayer in congregation is a confirmed sunna. Abandoning it is not authorized except for illness or other valid excuses. ${ }^{17}$ The former statement signifies the exemplary model of the Prophet (sunna) and the latter signifies duty (wujūb)."18

Here, al-Halabì highlights a seeming paradox inherent in the opinion delivered by al-Așl, a foundational text of the Hanafi school composed by Muhammad b. al-Hasan al-Shaybānī: "the former statement signifies the exemplary model of the Prophet (sunna)," while "the latter signifies duty (wujüb)." Indeed, these technical terms-sunna and wujüb-appear incompatible when one looks at a famous reference book on the definitions of key terms from various sciences that was sought after among the students of Rum: "words, deeds, and attitudes of the Prophet as well as the things that the Prophet habitually did without obligation" (sunna) versus "[an act] whose abandonment entails rebuke and punishment" (al-wujüb al-shar $\bar{\imath}) \cdot{ }^{19}$ While sunna is by definition not obligatory, wujūb requires sanctions, such as rebuke and punishment.

Al-Halabì devoted an entire section to explaining that in his opinion sunna and $w u j \bar{u} b$ were not necessarily incompatible when it comes to the normative value of the five daily congregational prayers and the penal sanctions to deter nonattendance. ${ }^{20}$ Without delving into how this incompatibility had found expression as well as resolution among the leading Ottoman Hanafi jurists of Rum, the significance of the decree of $944 / 1537-1538$ for imperial governance and religious politics cannot be fully appreciated. In order to shed light on this process, I will start by examining the discussions on the subject by two prominent Hanafi jurists from the lands of Rum: Bedre'd-din Mahmūd (d. 823/1420), a celebrated jurist who served briefly as the Ottoman military justice (kâdiécasker $)^{21}$ during the civil war among the Ottoman princes (804816/1402-1413),22 and Mollā Fenārī (d. 834/1431), who was remembered as the

17 Al-Halabī does not give a citation for this quote. I was able to locate the same passage in Khulāṣat al-fatāwā of Iftikhār al-Dīn Ṭāhir b. Aḥmad al-Bukhārī (d. 542/1147). See Iftikhār al-Dīn, Khulāṣat al-fatāwā 4 ob.

18 "Qāla Muḥammad fìl-Aṣl 'Tlam anna al-jamā'a sunna mu'akkada. Là yarkhuṣu al-tarkfì-hā illā bi-'udhri marad aw ghayrihi.' Wa-awwal hādhā l-kalām yufídu al-sunniya wa-akharihu yufidu al-wujūb." Al-Ḥalabī, Ghunyat al-mutamallī 508.

19 Al-Jurjānī, Ta'rīfāt 195, 345.

20 Al-Ḥalabī, Ghunyat al-mutamallī 508-510.

21 On Bedre'd-dīn Mahmūd, known also as Shaykh Bedre'd-dīn, whose jurisprudential career is overshadowed by his reputation as a leader of a messianic rebellion, see Balivet, Islam mystique; and Ocak, Zındıklar ve mülhidler 136-202. For a recent reassessment of this reputation, see Binbaş, Intellectual networks 129-132.

For a detailed analysis on the conflicts, see Kastritsis, The sons of Bayezid. 
first chief jurist of the Ottoman Empire by the later early modern biographical tradition. ${ }^{23}$ Thereafter, I will demonstrate how the Ottoman jurists resolved the debate in the tenth/sixteenth century through reaching a consensus before Sultan Süleymān issued the decree in 944/1537-1538.

The problem of the incompatibility between sunna and wujūb is traceable from the tension between Bedre'd-dīn and Fenārī on the normative value of the five daily congregational prayers. While Bedre'd-din considered the five daily congregational prayers as confirmed sunna, ${ }^{24}$ Fenāri thought that they are "akin to duty" (shibh al-wujüb). ${ }^{25}$ As we have seen in al-Halabī, this distinction had ramifications for the consideration of penal sanctions. Bedre'd-din dwelled upon the question from the standpoint of the call to prayer. He did so by reflecting on the difference of opinions between Abū Yūsuf Ya'qūb b. Ibrāhīm al-Anșānī (d. 182/798) and Muhammad b. al-Ḥasan al-Shaybānī (d. 189/8o5), the two prominent successors to the Hanafi school's eponymous founder, Nu'mān bin Thābit, known as Abū Hanīfa (d. 15o/767). For Abū Yūsuf, Bedre'd-dīn wrote, the call to prayer corresponds to a confirmed sunna rather than a duty. According to this stance, the ruler is bound to enforce an act if the act is a duty rather than a confirmed sunna (al-qitāl innamāyakūn 'alā tark al-wājib dūna alsunna). In contrast, for Muhammad al-Shaybānī, Bedre'd-dīn noted, the call to prayer (and the five daily congregational prayers) was a duty ${ }^{26}$ — this, as I will show below, was historically the majority opinion within the Hanafi school. The reasoning behind Muhammad al-Shaybāni’s opinion is that abandoning the call to prayer (and the five daily congregational prayers) connotes a disdain of Islam. Bedre'd-din maintained that the opinion that takes precedence is the one attributed to Abū Yūsuf unless the five daily congregational prayers are collectively and persistently abandoned. ${ }^{27}$ Although Fenārī agreed with Bedre'ddin on the ruler's duty to inflict punishment in cases of collective and persistent abandonment, he also demanded sanctions for any male Muslim individual who did not attend the masjid. ${ }^{28}$ In line with Muhammad al-Shaybāni’s moral justification, Fenārī maintained that the five daily congregational prayers are "from among the distinguishing marks of the religion" (min a läm al-dìn). ${ }^{29}$

\footnotetext{
23 On Mollā Fenārī see Repp, The müfti 73-97.

24 Bedre'd-dīn, al-Tashïl i, 75-76, 97.

25 Mollā Fenārī, Fușūl al-badāì i, 242.

26 Bedre'd-dīn, al-Tashïl i, 75-76, 97.

27 Ibid. 76, 97.

28 Mollā Fenārī, Fușūl al-badā'i i, 242.

29 Ibid. 243.
} 
By the turn of the tenth/sixteenth century, the Ottoman Hanafi jurists of Rum had resolved this conundrum and arrived at a consensus that paved the way for the decree of $944 / 1537-1538$. This is traceable from the reading notes of Sacdi Çelebi (d. 945/1539), ${ }^{30}$ who was the chief jurist (940-945/1534-1539) when Sultan Süleymān issued the decree in question. While reading the discussion on the normative value of the five daily congregational prayers from Akmal al-Dīn Muḥammad al-Bābartìs (d. 786/1384) authoritative commentary on a major Hanafi jurisprudential manual, Burhān al-Dīn al-Farghānī alMarghinānī’s (d. 593/1197) al-Hidāya, Sa'dī Çelebi recorded his emphatic consent to al-Bābartī's opinion that the five daily congregational prayers constitute "one of the characteristics of the religion" (min khașäiț al-dinn) and attendance is a duty. ${ }^{31}$ When discussing al-Marghināni’s opinion that the five daily congregational prayers constituted sunna al-hudā (i.e., confirmed sunna), al-Bābartī, a well-known Hanafi scholar who taught in Mamluk Cairo, argued that that the terms sunna and wujüb overlap in meaning in the context of this discussion. The tension between al-Marghinānī and al-Bābartī was based on the question of how the Prophet Muhammad's words should be interpreted: "the congregation is a sunna from among the sunan al-hudā (pl. of sunna al-hudā; i.e., confirmed sunna), which are not given up except by the hypocrite (munäfiq)." ${ }^{32}$ Al-Bābartī maintained that the term sunna al-huda $\bar{a}^{33}$ in the hadith is defined as an act of worship whose "observance provides guidance, [and] its abandonment leads to going astray."34 By drawing on this definition, al-Bābartī maintained that when reading the hadith, the word "hypocrite" (munäfiq) should be conceived as a "rebellious sinner" ('ạṣi $) \cdot{ }^{35} \mathrm{Al}$-Bābartīs interpretation of "hypocrite" as "rebellious sinner" brings out the question of penal sanctions because "rebellious sinner" constitutes a status that a Muslim is assigned for the failure to observe an act that corresponds to a duty. ${ }^{36}$ In this way, an act of confirmed sunna becomes a duty whose noncompliance leads to penal sanctions.

$30 \quad$ On Sa'dī Çelebi, see Repp, The müfti 240-244.

31 Sa'dī Çelebi wrote, "yes, but I say that as the majority of our masters maintain, it signifies a duty" (Aqūlu na'am lākin yufíd al-wujūb kamā dhahaba ilayhi 'āmma mashayikhinā). See Sa'dī Çelebi, Hāshiyya 346. Although Sa dī Çelebi's note starts with "yes, but I say," he in fact did not mean to oppose al-Bābartī. To the contrary, Sa'dī Çelebi gave an emphatic consent in the sense of "not just yes, but yes, indeed" to al-Bābartī's assessment of al-Marghinānī's opinion.

32 Al-Bābartī, al-'Ināya 284.

33 The terms sunna al-hudā (sunna of guidance) and sunna al-mu'akkada (confirmed sunna) are interchangeable. See al-Jurjānī, Tárīfāt 195.

34 Al-Bābartī, al-'Ināya 284.

35 Ibid.

$36 \quad$ Reinhart, Like the difference 216. 
Within the Hanafi school, there were other opinions that conceived the five daily congregational prayers as an obligation without the need to illustrate how the confirmed sunna and duty are compatible in the context of the five daily congregational prayers. It would have been arguably more straightforward to simply adopt the opinion that classified attendance at masjids as an obligatory act $($ fard $) .{ }^{37}$ While it may sound trivial, the difference between a duty and an obligatory act was an epistemological distinction exclusive to the Hanafi school. In the eyes of Hanafi jurists, the evidential basis of a duty conveyed probability rather than definite knowledge, while that of an obligatory act was established through definitive indications from the sources of law that left no room for doubt. This distinction manifested itself in the ramifications on the status of a Muslim who fails to comply with what was required. While failure to observe an obligatory act placed a Muslim outside of the community of believers (which could lead to execution in the extreme cases), failure to observe a duty did not lead to such exclusion but instead rendered a Muslim a "rebellious sinner."38

The Ottoman Hanafi jurists of Rum explicitly preferred the status of "rebellious sinner" in legal as well as moral terms. As part of the discussion to which Sa'dī Çelebi gave consent, al-Bābartī had also made the legal point that the duty to perform the five daily prayers in congregation is established by khabar wähid [hadiths reported by transmitter(s) varying from one to few people], which convey probability rather than definite knowledge. Thus, noncompliance can only lead to the status of "rebellious sinner" rather than "unbelief" (kufr).${ }^{39}$ The moral justification of the Ottoman jurists regarding attendance at the masjids for the five daily congregational prayers arguably shows that they sought to exhort the sultan's male Muslim subjects to observe the five daily congregational prayers rather than apply more extreme (and more unrealistic) sanctions. ${ }^{40}$

As we have seen, the question of penal sanctions for individual worshippers was precisely the difference between Bedre'd-dīn's and Fenārì's views in the

37 Al-Bābartī's contemporary and opponent Ibn Abī al-'Izz (d. 792/139o) was one of the Hanafi jurists who considered the performance of the five daily congregational prayers as an obligatory act ( fard $)$. See Ibn Abī al-'Izz, al-Tanbīh esp. 599-6o1. On a debate between al-Bābartī and Ibn Abī al-'Izz regarding the methods of rule formulation within the Hanafi school, see İnanır, İbn Ebi'l-İzz'in 225-26o.

38 Reinhardt, Like the difference, esp. 207-212, 215-216.

39 Al-Bābartī, al-Ināya 284.

40 This is comparable to the question of why the leading Ottoman Hanafi jurists addressed and resolved the issue of blasphemous phrases and deeds through recourse to "renewal of faith and marriage." Burak, Faith, law and empire 1-23, esp. 10-11. 
ninth/fifteenth century. Bedre'd-din may not have seen it as necessary to elaborate on the question of penal sanctions for the nonattendance of individuals at congregational prayers at the particular time that he wrote, which was one of the greatest political turmoil. However, as suggested by Çiğdem Kafescioğlu in this volume, over the second half of the ninth/fifteenth century, the question of clearly demarcated places of prayer became more central to Ottoman governance. This was reflected in the gradual separation of masjid from spaces with other accommodative and social functions within the imārets as well as the gradual transformation of the imarrets into congregational mosques starting in the 1510s. This growing emphasis on the places of prayer as sites of community building might have been one of the motives behind the chief jurist Sa'dì Çelebi's concern with the reconciliation between sunna and wujūb, thus opening the door for disciplining male Muslim subjects if they abandoned the five daily congregational prayers individually and collectively. Sa'dī Çelebi's reading note on al-Bābartī's discussion espoused his opinion by stating "as the majority of our masters maintain, it signifies a duty," which indicates that Sa'di Çelebi saw this reconciliation as reflective of a consensus among the leading Ottoman jurists. Here, "the majority of our masters" did not only signify that conceiving of the five daily congregational prayer as a duty was the majority opinion within the history of Hanafi school. ${ }^{41}$ It also signified the stance of the leading jurists within the Ottoman Empire who were on board with this majority opinion throughout the late ninth/fifteenth and the tenth/sixteenth centuries. Indeed, apart from Sa'dī Çelebi, established jurists such as Mollā Hüsrev (d. 885/148o), ${ }^{42}$ Çivizāde (d. 954/1547), ${ }^{43}$ al-Ḥalabī (d. 956/1549), ${ }^{44}$ Birgivī Meḥmed (d. 981/1573), ${ }^{45}$ and Ebū's-su ūd (d. 982/1574), ${ }^{46}$ whose opinions had on occasion provoked controversies on important jurisprudential issues, ${ }^{47}$ all agreed that the five daily congregational prayers constituted a duty.

The consensus that underlined the decree of 944/1537-1538 was the result of tremendous political, religious, and institutional changes that took place in the lands of Rum from the late eighth/fourteenth to the early tenth/sixteenth cen-

41 Sa'dī Çelebi is not the only Rumi jurist who acknowledged the presence of this majority opinion within the history of the Hanafi school. See Ibn Melek, Sharh majma' al-bahrayn 31a; Chiwīzāde, al-İthār 174. See also al-Ḥalabī, Ghunyat al-mutamallī 508.

42 Mollā Hüsrev, Mirqāt al-wușūl 278.

43 Chiwīzāde, al-İthār 173.

44 Al-Ḥalabī Ghunyat al-mutamallī 508-510.

45 Birgivī Meḥmed, Jalä’ al-qulūb 63.

46 Ebū Su'ūd, Zur Anwendung 24-25.

47 See Özen, Molla Hüsrev'in velâ meselesi 321-394; Mandaville, Usurious piety 289-308; Terzioğlu, Bid'at, custom, and the mutability (forthcoming). 
turies. By the time Sa'dī Çelebi was appointed as the chief jurist in 940/1534, the Ottoman dynasty had already established political control over much of the Balkans and the Middle East. However, the dynasty was confronted by the crisis of legitimacy along with this territorial expansion. Between 917/1511 and 944/1537-1538, central and southern Anatolia was swept by messianic and antinomian revolts in the countryside, some of which were inspired by the rise of the Shi'ite Safavid Empire in Iran. ${ }^{48}$ While experimenting with messianic discourses in an attempt to reconceptualize the notion of the caliphate, ${ }^{49}$ the Ottoman sultans and their advisers also drew on the legal and moral idiom that a new class of scholars and jurists under their patronage provided to enhance the coercive function of the state to discipline Muslim subjects in line with the changing understanding of the requirements for belonging to the Sunni Muslim community. 50

In contrast to the consolidation of Ottoman power in the tenth/sixteenth century, the climate in which Mollā Fenārī and Bedre'd-dīn lived was markedly different. The lands of Rum were fragmented and ruled by various dynasties that competed against each other not only through warfare and diplomacy but also by extending patronage to scholars and jurists from different parts of Islamdom. ${ }^{51}$ Despite these efforts, the lands of Rum were still peripheral to the eminent centers of Islamic learning in Syria, Egypt, and Central Asia. Like many Rumis at the time, Fenārī and Bedre'd-dīn had to seek jurisprudential education in Mamluk Cairo, where they were taught by none other than al-Bābartī. ${ }^{52}$ Unlike the tenth/sixteenth century when the Ottoman dynasty had a concentrated network of high-level scholars and well-funded royal madrasas, ${ }^{53}$ the relationship of jurists with the dynasties of Rum were relatively fluid in the late eighth/fourteenth and the early ninth/fifteenth centuries. Mollā Fenārī, who was remembered as the first Ottoman chief jurist, spent an important

48 See Sohrweide, Der Sieg der Safaviden, especially 145-186; Ocak Idéologie 185-192.

49 See Yllmaz, Caliphate redefined. On Ottoman messianism as well as its cultural and intellectual references, see Fleischer, The lawgiver as Messiah 159-177; Fleischer, Learning and sovereignty 155-16o. See also Flemming, Sāḥib-ḳırān 43-62.

50 See Burak, Faith, law and empire 1-23; Aykan, A legal concept in motion 1-19. See also Derin Terzioğlu's article in this volume.

$51 \quad$ See Peacock and Yildız, Introduction 19-42, esp. 23-28.

$5^{2}$ See Ökten, Scholars and mobility 55-70; Atçıl, Mobility of scholars 315-332; Ylldız, From Cairo to Ayasuluk 263-297, for a discussion on al-Bābartī and his Rumi students, see esp. 266-268.

53 With respect to the institutional history of the Ottoman learned class, studies have demonstrated the formation, bureaucratization, and hierarchization of the learned establishment into a single central system with fairly standardized and graded training and career tracks across the empire by the mid-sixteenth century. For the most recent monograph on this process, see Atçl, Scholars and sultans. 
part of his career under the patronage of the Karamanid dynasty in central Anatolia. ${ }^{54}$ Bedre'd-dīn for his part wrote a sizable commentary on his own jurisprudential book while in exile following the murder of Ottoman prince Mūsā Çelebi (d. 816/1413) and completed it after the outbreak of the messianic rebellion against the Ottoman dynasty in which he himself would be implicated. ${ }^{55}$ When Sultan Süleymān issued the decree in 944/1537-1538, however, Sa'dī Çelebi was presiding over a class of scholars and jurists who were embedded within an imperial system for the production of knowledge and authority and who readily provided the language and legitimacy to the political exigencies of the time..$^{56}$

It appears that the Ottoman authorities punished collective and persistent abandonment of the five daily congregational prayers even before Sultan Süleymān's decree signaled the reconciliation of sunna and wujūb to sanction punishment for individuals and communities who did not attend the masjids. For example, the chief jurist Kemālpaşazāde, also known as Ibn Kemāl (d. 940/1534), who held the office of chief jurist between 932/1526 and 940/1534, was asked "what punishment is required by law for the people of a neighborhood or a village who do not attend the daily congregational prayers even though they are healthy and fit." ${ }^{57}$ Moreover, as the fatwa makes it clear, the people in question remained recalcitrant in the face of repeated exhortations on the part of imam and muezzin (imām ve müezzin tenbih eyleseler), to which Kemālpaşazāde prescribed severe discretionary punishment. ${ }^{58}$ The fatwa features a confrontation in which imams and muezzins approach the people who refuse to attend the masjid. This was the kind of collective and persistent abandonment that Bedre'd-dīn and Fenārī had in mind for which both of them thought that the penal sanctions were justifiably applicable.

At the heart of the issue is the lack of a valid excuse for the failure to perform the prayers collectively as the fatwa stresses that the people who are supposed to attend the masjids are "healthy and fit" (șăg ve sālim) Muslims. As

54 On the mobility of scholars and Sufis between the Ottoman and Karamanid realms in the ninth/fifteenth century, see Karataş, Onbeşinci yüzyllda Karamânî $283^{-298}$, on Fenārī, see esp. 284-285, footnote 6; see also Atçl, Scholars and sultans 42.

55 Binbaş, Intellectual networks 131 .

56 On the relationship between the institutionalization of the Ottoman learned establishment and the emergence of the Ottoman branch of the Hanafi school, see Burak, The second formation.

57 For variant copies of the fatwa, see İbn Kemāl, Fetā $v \bar{a}$, Süleymaniye Kütüphanesi, MS Darülmesnevi 118, 32b; and Ms Hacı Mahmud Efendi 1224, 152b; The fatwas are also cited in İbn Kemal, Şeyhülislam İbn Kemal 154. 
such, the fatwa's reasoning rests on the relationship between law and exemption $(r u k h s ̣ a)$ in legal theory (ușül al-figh). Accordingly, people were granted exemption from a responsibility only when they suffered from a hardship recognized by law. Otherwise, law retained its force ('azima).${ }^{59}$ Seen in this light, for Kemālpaşazāde, it was legally unacceptable not to attend the masjids for the community of able-bodied male Muslims without a valid excuse.

As this convergence between Mollā Fenārī, Bedre'd-dīn, and Kemālpaşazāde shows, the opinion that upholds punishment for collective and persistent abandonment had been circulating earlier than the tenth/sixteenth century. In fact, it is possible to trace the initial experiments with an official punishment policy before the tenth/sixteenth century not only for the cases of collective and persistent abandonment but also for the cases in which each and every settled, able-bodied, adult male Muslim habitually neglect performing the five daily prayers with the congregations. As Derin Terzioğlu points out, the office of prayer-enforcer (namāzcl) had been established around the last years of Mehmed II's reign and its job description was to fine the habitual absentees from the five daily congregational prayers. Moreover, Terzioğlu notes, the sultanic law code of Bāyezìd II indicates a continuity given that the monetary punishment upon the absentees was put in a set of clauses. ${ }^{60}$ One can, thus, argue that the opinion that underpins Süleymān's decree had already acquired footing in the decisions of the political authority within the second half of the ninth/fifteenth century, half a century earlier than the rise of the Shi'ite Safavid Empire. However, over the course of the first half of the tenth/sixteenth century, the authorities' attention to the attendance at congregational prayers and spaces where they were to be performed increased significantly in tandem with the growing concern for building a Sunni community and monitoring its boundaries.

The legal consensus expressed by Sa'dī Çelebi found political confirmation not only through the decree of 944/1537-1538 but also through Ebū's-su'ūd's fatwa in which he confirms that the decree is still valid. We can demonstrate this based on an annotation found within Ma'rū book of Ebū's-su'ūd's fatwas with bibliographical annotations in Arabic that reveal preferred opinions on the jurisprudential questions, which were confirmed by Sultan Süleymān. ${ }^{61}$ By quoting from Khizānat al-muftīn-a com-

59 Katz, 'Azïma and rukhșa 188-189. It is precisely with reference to this very distinction between the original rule $(a s ̧ l)$ and the valid excuse ('udhr) under which Mollā Fenārī had expressed his opinion that the five daily congregational prayers were tantamount to duty (li-muta'alliqi al-ḥukm bi-ítibār al-'udhr al-makhraj 'an aṣlihi). See Mollā Fenārī, Fușūl albadāici i, 240.

6o Terzioğlu, How to conceptualize 313-314. For further insights on this point, see Çiğdem Kafescioğlu's article in this volume.

61 Ebū Su'ūd, Zur Anwendung 24-25. 
pendium of jurisprudential opinions composed in $740 / 1398$ by a Hanafi jurist Ḥusayn b. Muḥammad al-Sam'ānī-the annotation provides the reader with a moral justification for the continuing validity of the decree:

The call to prayer is one of the manifest signs of Islam (shacäir al-isläm), ${ }^{62}$ thus, if the people of a city or a village or a neighborhood refrain from it, the ruler coerces them. If they do not abide, he fights against them with arms. And, if the people of a city abandon the call to prayer (adhān) and the call to perform prayer (iqāma $)^{63}$ and the five daily congregational prayers $(j a m \bar{a} a)$, then the ruler fights against them, since they are of the religion's landmarks and its manifest signs. Khizānat al-muftīn. ${ }^{64}$

As we have seen, this justification echoes al-Bābartìs opinion through which the chief jurist Sa'di Çelebi expressed his endorsement of the view that the five daily congregational prayers constituted a duty. The annotation of Ebū's-su'ūd's fatwa makes this endorsement enforceable by stating that one of the major duties of the ruler was to safeguard the five daily congregational prayers from negligence. If they are not observed, the ruler must have recourse to coercion (ajbarahum). If they are persistently abandoned, the ruler must have recourse to violence (qātalahum; qātalahum bi'l-silāh). It is not a coincidence that both found expression in the decree: while coercion was to be employed in enforcement of building a masjid (cebrile mescid bina etdürüb), violence was implicit in stipulating discretionary punishment ( $t a$ z $z i r)$ for habitual absentees. The justification is imbued with concerns over confessional boundaries: "they are of the religion's landmarks and its manifest signs," meaning they are distinct and specific to Islam, and thus, the ruler has to make sure his male Muslim subjects distinguish themselves in daily life through observing these acts of worship that are inherently public and communal. ${ }^{65}$ In this respect, Ebū's-su'ūd's fatwa

62 On the various meanings of shi'ār (pl., sha'ä̉ir), see Fahd, Shicār 424; Özervarl,, Şiâr 123-124.

63 The difference between adhān and iqāma is that iqāma serves to let those who have congregated know that the prayer is about to commence, be it the five daily congregational prayers or the Friday noon prayer. After repeating the words of the adhān, the muezzin adds "qad qāmati al-șalāt," that is "now begins the prayer." See Juynboll, Ikāama 1057; Akyüz, İkāmet 16-17.

64 "Inna al-adhān min sha'āir al-isläm ḥattā law imtina' ahl mișrin aw qaryatin aw mahallatin ajbarahum al-imām fa-in lam yaf'alū qātalahum bi'l-silāh. Wa law anna ahla mișrin taraka al-adhāna wa al-iqāma wa al-jamā'a qātalahum al-imām li-annahu min mààlim al-dìn wa sha'āirihi. Khizānat al-muftīn." Ebū Su'ūd, Zur Anwendung 24-25 (my transliteration).

65 This normative Sunni discourse on religion (dīn) vis-à-vis the call to prayer, call to perform prayer, and the five daily congregational prayers had highly divisive as well as unifying overtones. It is plausible to suggest that this discourse informed some of the policies 
reflects the success of the consensus in which both the leading Hanafi jurists and the sultan saw a desirable idiom to formulate the scope of sultanic authority in enforcing the divine laws on earth.

Not only did the presence of the consensus within the Ma'rüḍat render the sultan responsible, but it also provided the institutional framework for the Ottoman dynasty to become directly involved in the religious lives of male Muslims in public by enforcing the congregational performance of the five daily prayers in the masjids. The governors and judges of the empire were required to comply with the opinions espoused in the Ma'rüdāt even after Süleymān's reign. As expressed in the preface ${ }^{66}$ of the $M a{ }^{\prime}$ rü $q \bar{a} t$, throughout his career, the chief jurist Ebū's-su'ūd submitted his fatwas to Sultan Süleymān with an aim to clarify many disputed jurisprudential issues and express his conviction to abide by them. ${ }^{67}$ By doing so, the preface notes, Ebū's-su'ūd selectively engaged with the erstwhile authorities from age-old jurisprudential traditions for the necessity to attain order in religion and state as well as regularity in the realm's state of affairs. In his turn, Sultan Süleymān promulgated decrees in accordance with Ebū's-su'ūd's fatwas. Although the governors and the judges were accustomed to abide by the opinions, the preface continues, some of them were resubmitted in order to dispel doubts as to how to resolve the jurisprudential issues after the renewal of the regal power with the succession of new sultans from

towards the Kızılbaş-Alevis in the Ottoman Empire during the tenth/sixteenth century. For a very brief but insightful discussion on a call for a demanding task to historicize Muslim conceptions of din that were marginalized by the traditions of scholarly Islam, see Karamustafa, Islamic din 167-168. For some of the recent contributions on the KızlbaşAlevis and the religious policies of the Ottoman authorities toward these communities, see Baltacıoğlu-Brammer, The formation 21-48; Karakaya-Stump, The Kizilbash-Alevis; Ylldırım, Turcomans between.

66 "Sultanım hazretleri arz-ı dâti-i bî-minnetleri oldur ki; bundan akdem merhûm Şeyhülislâm Müftîl-enâm Allâme-i zamân Fehhâme-i evân Efdalü'l-mevcûd Mevlânâ Ebussuûdyesserallâhu'l-makâme'l-mahmûd Sultân-ı zemîn u zemân Halîfe-i Rabbill-âlemîn cennetmekân hümâ-yı kuds-âş̧iyân Ebu'l-feth en-nasr es-Sultân Süleyman Hân aleyhir-rahmetü ve'r-rıdvân hazretlerine nizâm-ı dîn u devlet ve intizâm-ı ahvâl-i memleket iktizâ etmeğin ba'zı mesâilde eimme-i dinden ba'zı müctehidin rıdvânullâhi teâlâ ecma'în kavilleri üzere amel eylemek münâsib olduğun arz buyurub ol minvâl üzre amel olunmağa ferman-ı sultân $\hat{\imath}$ ve hükm-i cihân-bânî sâdır olub vülât-ı İslam ve kuzât-ı hükkâm ol vechile amele mu'tadlarıdır hâlen serîr-i saltanat ve pâye-i hilâfet tecdîd-i sânîile mücedded olub hadîka-i saltanat tâze behcet ve riyâz-ı hilâfet cedîd nusret bulıcak emr-i sultânî ve hükm-i hâkânî zikr olunan mesâilde ne minvâl üzre idiğine iştibâh olmağın ahvâl müşkil olub keșf u beyân ve emr-i Pâdişâhî ıyân buyurulmak recâsına vâki olam mevâddın ba'zı arz olundu. Bâkîfermân men lehu'l-emrindir. Halledellâhu sübhânehû ve teâlâ ve bi fazlihi." See Ebussuûd, Ma'rûzât 44.

67 For the significance of the Ma'rūḍat, see Imber, Süleyman as caliph 180-182; Ayoub, "The sulțān says" 239-278. 
the Ottoman dynasty. ${ }^{68}$ Yet, it is important to keep in mind that when Sultan Süleymān issued the decree in 944/1537-1538, the chief jurist was Sa'di Çelebi and the function of Ebū's-su'ūd's fatwa was just to affirm its continuing validity.

As the governors and judges were expected to follow the Ma'rūdatt, the consensus on the normative value of attending the five daily congregational prayers retained its force in the eleventh/seventeenth century at the individual and communal level. The work by Mevḳūātī Mehmmed of Lesbos (d. 1065/1654) provides an illustrative example of this continuity. While elaborating on the compactly formulated opinion that the "five daily congregational prayers constitute a confirmed sunna" (al-jamā'a sunna mu’akkada) in Ibrāhīm al-Ḥalabī's Multaqā al-abḥur, Mevḳūātì's commentary seamlessly relates sunna to duty. Unlike al-Halabī's long discussion on the subject in a separate book (Ghunyat al-mutamallī), Mevḳūātī clarifies the consensus in a laconic way: "[performing] five daily prayers in congregation constitutes a sunna that is tantamount to a duty" (kuvvetde vācib meșäbesindedir). ${ }^{69}$ Gone are the rather lengthy justifications for resolving the incompatibility between sunna and duty from the previous century.

\section{4}

\section{Who Can Lead the Prayer? Imams as Models of Correct Practice}

The Ottoman Hanafi jurists of Rum were not just concerned about the attendance at the five daily congregational prayers. They were also preoccupied with different ritual and moral duties related to imams that had a bearing on the prayer itself. In his memorably pessimistic monologue on human experiences across various strata of Ottoman society, the celebrated polymath Muștafā 'Ālī (d. 10o8/16oo) described the challenges of imams in the following way:

Listen, $\mathrm{O}$ you who know the truth of things!

This speech will purify you in the way gold is purified. [...]

The fight for one's living is a universal calamity;

In it there is no exception for any individual. [...]

Let us suppose you were an imam or a preacher. [...]

Many have performed their ritual prayers behind you.

A wondrous self-conceitedness has appeared in you.

68 Ebussuîd, Ma'rûzât 44 .

69 Mevḳūfātī Meḥmed, Şerḥül-Mevkūuāāī i, 79. See also, Dāmād Efendi, Majmū̌a al-anḥur i, 161. 
If you lack in regular attendance to your duty,

The judge will at once reprimand you.

If you commit an error contrary to Divine Law,

The civil administrators will sentence you to the punishment of the whip.

If during the ritual prayer you break wind, [...]

Then, the congregation that worshipped behind you

Will become the cause of your punishment. ${ }^{70}$

According to Muștafā 'Ālì, being an imam meant being under the watchful eyes — and ears—of his neighborhood. Surely, to "break wind" may sound a rather petty misdeed for the congregation that worshiped behind the imam to "become the cause of his punishment" compared to "lack in regular attendance," or "an error contrary to shari'a." However, the misdeed in question does not merely signify the imam's ritual impurity (hadath) that risks the validity of his congregation's prayer. The additional layer of meaning is also reflected in a common proverb, equally famous back then, as the Lețāif of Lāmi'ì Çelebi (d. 938/1532) suggests: "When the imam breaks wind—as this is to the people a proverb well beknown - then no wonder if the rest of the community shits," which might have inspired Muștafā 'Ālì's choice of words. ${ }^{71}$ At stake is the compromised image of an imam (muktedā) as a model (kıdve) his neighborhood should follow (iktid $\bar{a}) .{ }^{72}$ To serve as an imam was not confined to meeting the ritual requirements. An imam had to display moral behavior. Practical skills in leading the prayer as well as proper conduct in daily life had a bearing on an imam's career.

In their respective discussions on the evolving notions of Sunni orthodoxy and orthopraxy among the Ottoman authorities between the mid-ninth/midfifteenth and mid-tenth/mid-sixteenth centuries, Gülru Necipoğlu and Derin Terzioğlu have suggested that the neighborhoods became the sites of social disciplining and community monitoring. ${ }^{73}$ Necipoğlu emphasized that neighborhoods (mahalle) were reorganized in the tenth/sixteenth century around the local masjids and represented by their imams and muezzins. They were appointed by the royal diploma (berāt) based on the recommendation of the

70 Tietze, The poet 145,156 (translated by Tietze).

71 Lāmi'ī Çelebi, Letā'if 257b.

72 Ahterî, Ahterî-yi kebir 99, 750, 89.

73 Necipoğlu, The age of Sinan 47; Terzioğlu, How to conceptualize 315; Terzioğlu, Where 'ilm$i$ hăl meets catechism 101. 
local community and paid from the masjid's endowment. ${ }^{74}$ Necipoğlu and Terzioğlu have also pointed to Ebū's-su'ūd's fatwas that discouraged attendance at congregational prayers outside of one's own neighborhood, which in turn enabled imams, muezzins as well as the pious Sunni Muslims to monitor regular attendance. ${ }^{75}$ However, while imams sought to enforce and sustain piety as official intermediaries between the state authorities and the neighborhoods, the communities, too, kept an eye on their imams. The neighbors could also resist or even denounce the imams to the authorities. This mutual moral surveillance upheld by the Hanafi school ${ }^{76}$ drew on a particular liturgical bond between the imams and their congregations.

In terms of ritual requirements, in the Hanafi school the validity of the prayers of the entire congregation depends on the validity of the imam's prayer, which in turn makes the imam liable to his congregants. ${ }^{77}$ This Hanafi opinion is traceable among the scholars in the Ottoman lands of Rum as early as the ninth/fifteenth century. Bedre'd-din adduces this opinion through a hadith: "the imam constitutes the warrantor of the congregation's prayer."78 With reference to this hadith, Bedre'd-din formulates the legally binding norm as follows: "whether the congregation's prayer is valid or void hinges on whether the imam's prayer is valid or void."79 The responsibility of imams as "warrantor" (dāmin) stands out as an important marker of difference for the Hanafi school as Bedre'd-din explicitly contrasts it with the Shafi'i opinion, which maintains that praying behind an imam means praying in conformity with him and nothing more and that the validity of his prayer is independent from the validity of the congregation's prayer. ${ }^{80}$ Bedre'd-din mentions that the basis of the Shafi' $i$ opinion is a different hadith: "indeed, the imam is appointed just to be followed [by those praying behind him]." 81

74 Necipoğlu, The age of Sinan 47. It goes without saying that imams and muezzins were not the only representatives of Muslim neighborhoods, nor were the neigborhoods strictly divided as Muslim and non-Muslim neighborhoods. For an overview, see Ergenç, Osmanlı şehrindeki “mahalle"nin 69-78.

75 Necipoğlu, The age of Sinan 49; Terzioğlu, How to conceptualize 315; Terzioğlu, Where 'ilm$i$ h $\bar{a} l$ meets catechism 101.

$7^{6}$ The phenomenon of moral surveillance was an extension of the collective responsibility (and liability) of a community that was bound together based on spatial proximity in the form of a neighborhood or a village. On an essay as to the jurisprudential roots of collective responsibility and its development within the Ottoman period, see Canbakal, Some questions $131-138$. On the moral discourses of neighborly relations in the early modern Ottoman history, see Tamdoğan-Abel, Les relations de voisinage 167-177.

77 Katz, Prayer 138, footnote 50.

78 Bedre'd-dīn, al-Tashïl i, 100.

79 Ibid.

8o Ibid. 101-102.

81 Ibid. 
This difference of opinion between the two legal schools did not prevent certain Hanafi congregations from praying behind Shafi'i imams. The reason appears to have been related to a chronic shortage of male Muslims capable of leading the prayer in the Hanafi way. Judging from the questions posed to the chief jurists from the tenth/sixteenth and the eleventh/seventeenth centuries, the view that the imam is the "warrantor" to the validity of his congregation's prayer exercised a degree of influence in such circumstances, but at no point was the opinion fully enforced in order to avoid discouraging attendance at the daily congregational prayers. When a Hanafi congregation wondered whether it is permissible to pray behind a Shafi'i imam, for instance, Ebü'ssu'ūd allowed the Shafi'i imam to lead the Hanafi congregation, but with one caveat: "it is permissible, if the Hanafi congregation feels convinced that the Shafi'i imam preserved his ritual purity throughout the act of worship (ābdestinde halel yok idüğüne 'itikād edecek, olur)." ${ }^{22}$ Here, Ebū's-su'ūd espouses the Hanafi opinion about the imam being the "warrantor" in its rudimentary form, while also recognizing the legitimacy of ritual differences between the Shaf'i $i$ imam and the Hanafi congregation at the same time. ${ }^{83} \mathrm{He}$ does so by expecting the Hanafi congregation to be attentive to the Shafi'i imam's ritual purity rather than requiring the Shafi'i imam to abide by the Hanafi way of leading the prayer. In the same spirit, when Es'ad Efendi (d. 1034/1625) assents to the court's dismissal of a Shafi'i imam on the grounds that the Hanafi congregation managed to find a Hanafi imam, he does so tactfully by avoiding the word "dismissal" ( $a z l)$ in his answer: "it is appropriate for the judge to replace [the imam]." ${ }^{84}$ Es'ad Efendi's reasoning appears to be on a par with Ebü's-su'ūd's: there is essentially no harm in prayer behind a Shafi'i imam, an opinion of the famous Transoxanian jurist Qādī Khān (d. 592/1196) that is indicated through an annotation as a marginal note within the compilation of Es'ad Efendi's fatwas. ${ }^{85}$

Moreover, in line with the Hanafi school, Ottoman Rumi Hanafi jurists thought that jurisprudential knowledge and recitation of the Quran constituted the two foremost qualities of a competent imam as both were inte-

\footnotetext{
82 Ebū's-su'ūd, Fetāvāa-yı Ebū's-su'ūd $12 b$.

83 On the question of prayer behind an imam of another legal school, see Katz, Prayer 150155 .

84 "Mes'ele: Bir mescid-i şerīfin cemāáati cümle Hanefiül-mezheb iken mescid-i şerīfin imāmı Şāf fü̈l-mežheb olsa cemā'ati imām-ı merkūmu imāmetinden 'azl etdirüb Hanefiül-mežhebi imāmı naṣb etdirmeğe ḳādir olurlar mı? El-cevāb: Hākime münāsib olan tebdīl etmekdir." See Es'ad Efendi, Fetāvā-yı müntehab 6a.

85 Ibid.
} 
gral to leading the prayer. ${ }^{86}$ Imams of such caliber certainly did exist. They embodied the juristic ideal to maintain the correct performance of prayer as painstakingly as physicians maintained the well-being of a human, a simile drawn by the Ottoman scholar Țāşköprüzāde (d. 968/1561). ${ }^{87}$ Yet they were by no means a norm and sources suggest that in some parts of the empire capable imams were difficult to find, thus raising the question of the validity of many a congregation's prayers. ${ }^{88}$ At times, the chief jurists had to certify the imams whose physical challenges would potentially disrupt the prayer (e.g., inguinal hernia ${ }^{89}$ deafness,${ }^{90}$ epilepsy,,${ }^{91}$ senility, ${ }^{92}$ lameness, ${ }^{93}$ amputeeness, ${ }^{94}$ incontinence, ${ }^{95}$ blindness $\left.{ }^{96}\right)$. The reasoning is predictable-necessity (żarüret) - since no other person knew how to perform the duty in the community.

Certainly, some places were more fortunate than others in having a pool of qualified candidates. Take the case of Istanbul. The famous poet Zātī (d. 953/ 1546), for instance, was rejected by his neighbors, when the imam of his neighborhood decided to set out on a pilgrimage and thought Zāâi worthy of temporarily taking his place. ${ }^{97}$ It apparently made no difference that Zātī felt confident enough in his knowledge of Islamic jurisprudence to even consider himself fit for a deputy-judgeship of Edirne, Bursa, and Istanbul. ${ }^{98}$ Judging from Zātî's background, however, his neighbors may have had good reasons for not considering him as worthy of serving as an imam. Zātī came from a humble artisan background rather than a family of jurists and had no known formal training. Even though his gift in poetry opened the doors of powerful men from the grand viziers to established scholars and even the sultan, he was not considered fit for this position. ${ }^{99}$ His poor hearing may have also played a role in being

86 Bedre'd-dīn, al-Tashīl i, 98; Mollā Hüsrev, Durar al-ḥukkām i, 68.

87 Ṭāşköprüzāde, Miftāḥ al-sa‘āda 182.

88 At the turn of the tenth/sixteenth century, Prince Korḳud (d. 919/1513) complained to his father Sultan Bāyezīd II by noting that in the countryside Muslims are religiously illiterate and the daily prayers are neglected. See Fleischer, From Şeyhzade Korkud 71.

89 Ebū's-su'ūd, Fetāvā-yı Ebū's-su'ūd iga.

$90 \quad$ Es'ad Efendi, Fetāvā-yı müntehab 6a.

91 Zekerīyāzāde Yaḥyā, Fetāvāa-yı Yahyyā Çelebī za.

92 Ibid. 2a.

93 Minḳārīzāde Yahyyā, Fetāvāa-yı Ațā̉ullāh 6a.

94 Çatalcalı Ali, Açıklamalı i, 20.

95 Feyzullah Efendi, Fetâvâ-yı Feyziyye 9.

96 Yenişehirli Abdullah, Behcetü'l-fetâvâ 35 .

97 Çavuşoğlu, Zâtî̀nin letâyifi 44.

98 Ibid. 41.

99 Kim, The last of an age 31-49; Çavuşoğlu, Zâtî'nin letâyifi 41. 
rejected ("Z̄âtī, your hardness of hearing makes an office impossible for you," he was told by the court officials ${ }^{100}$ ) since ability to hear well was important for imams to lead the prayers as well as to fulfill administrative responsibilities of a neighborhood.

At one level, the qualifications expected from an imam to lead a formally correct prayer overlapped with the qualifications that were desirable for his moral duty to guide Muslims to live a pious and law-abiding life. As Mollā Fenārī tellingly puts in his discussion on the concept of forbidding (al-nahy), vices (qubuh) are of two kinds: those (qubuh li-'aynihi) that one can discern merely by physical senses ('an al-hissiya $\bar{t}$ ) "such as drinking wine, fornication, or homicide," and those (qubuh li-ghayrihi) that one can fully grasp by recourse to sharia ('an al-sharīa $\bar{t}$ ) in matters "such as prayer, sale, marriage, or rent."101 Even when they met these standards, some imams did not know enough Arabic to even recite a verse from the Quran without distorting its meaning, ${ }^{102}$ let alone being able to read texts on the matters of law and piety. Seen in this light, lacking the qualifications that the jurists expected from imams could at times become a barrier to upholding law and religion of sharia in the neighborhoods or villages no less than leading the prayer in a correct manner. This juncture between the knowledge necessary for leading the prayer and offering moral guidance may be compared, as Terzioğlu suggests, with Protestant and Catholic parishes of Europe, which were similarly faced with lack of qualified personnel for the religious and social disciplining of local communities throughout the early modern period. ${ }^{103}$

This convergence between the ritual and moral aspects of serving as an imam brought to the fore another debate rooted in the history of Islamic jurisprudence: the question of whether or not congregational prayer behind a sinful imam is permissible. The basic contours of the debate, including both legal and moral points of view, are traceable to the medieval period. As a renowned Andalusian Maliki jurist Ibn Rushd (Averroes, d. 595/1198) notes in his book on differences of opinion, the question is a matter of debate among the Sunni schools of law. At one end of the spectrum, some held that the ability to lead the congregation correctly was the sole criterion, an opinion that flows from a legal rationale. At the other end of the spectrum, others viewed sinful imams through a moral lens. By drawing on an analogy (qiyās) with witnessing, they held that an imam must be a person of probity ('adl). Accordingly, just as

\footnotetext{
$100 \mathrm{Kim}$, The last of an age 37.

101 Mollā Fenārī, Fușūl al-badā'i ii, 41.

102 Minḳārīzāde Yahyā, Fetāvā-yı 'Ațāullāh 8a.

103 Terzioğlu, How to conceptualize 322.
} 
one must trust a witness to tell the truth, one must trust an imam to perform a valid prayer behind him. Thus, the unreliability of an imam would invalidate the prayer. ${ }^{104}$

Tijana Krstic traced the echoes of this debate in Ottoman catechisms from the latter part of Sultan Süleymān's reign, which were written to instruct Turkish-speaking Rumi Muslims in the basics of creed and piety. She observes that authors like 'Abdu'r-raḥmān bin Yūsuf Aḳsarāȳ̄, Birgivī Meḥmed, and Lüțfī Pasha emphasized that one of the key attributes of belonging to "the people of the Sunna [True Path] and the Community" was following imams in congregational prayers regardless of whether they are sinful Muslims or not. ${ }^{105}$ Krstić suggests that this jurisprudential view was implicitly connected with how Ottoman Sunni Hanafis envisaged imamate vis-à-vis sin in contrast to the Safavid Shi'ites. As Krstić suggests, it is not a coincidence that 'Abdu'r-rahmān bin Yūsuf Akssarāyī discusses the question of prayer behind a sinful imam in the context of a summary of the Sunni creed. ${ }^{106}$ She maintains that Aksarāyī here contrasts the Sunni view that "imams are not expected to be infallible or without sin," with the Shi'ite belief that the imam was immaculate. Some of the opponents of the Friday congregational prayer in the Safavid Empire argued that in the absence of the immaculate imam, who was in occultation, or of his designated representative, the Friday prayer was in abeyance and the shah did not have the right to convene it. 107

While in the Sunni tradition the question of the infallibility of the imam as a political leader may seem a separate matter from the question of a sinful imam as a prayer leader, the two were in fact linked. The link between the imām al-kubrā (greater imam, i.e., ruler) and imām al-ṣughrā (lesser imam, i.e., prayer leader) persisted within the Sunni tradition. It was due to this link that the Ottoman Rumi Hanafi jurists also had the "greater imam" in mind while discussing the jurisprudential question of prayer behind a sinful imam. This link finds expression in Mollā Hüsrev's (d. 885/148o) discussion on the analogy drawn between a witness and an imam. Although Mollā Hüsrev himself thought that prayer behind a sinful imam is permissible, ${ }^{108}$ he did not fail to explain the basis of opposing moral opinion within the Hanafi school. As I discussed above, the necessity for an imam to be a person of probity was based

\footnotetext{
104 Katz, Prayer 142.

105 Krstić, State and religion 72, 74, 75.

106 Ibid. 72.

107 Ibid. On different arguments in the Safavid debate regarding the Friday prayer, see Stewart, Polemics and patronage, esp. 428.

108 Mollā Hüsrev, Durar al-ḥukkām i, 68.
} 
on an analogy with the question of who deserves to be a witness. Analogy with a witness, Mollā Hüsrev noted, is not confined to prayer leaders (al-imāma), but also includes the guardians (al-wilāya), the judges (al-qaḍa $)$, and the rulers (al-saltana). ${ }^{109}$ In light of Mollā Hüsrev's explanation, it makes sense why, as Krstić notes, 'Abdu'r-raḥmān bin Yūsuf Akssarāyī wrote "imams are not expected to be infallible or without sin," while maintaining that prayer behind a sinful imam is permissible. ${ }^{110}$ What he meant was that in the Sunni tradition, imams were not expected to be infallible, whether they were prayer leaders or rulers. By doing so, 'Abdu'r-raḥmān bin Yūsuf Aḳsarāyī implicitly highlighted the link between the ruler and the prayer leader in order to contrast it with the Shi'ite tradition.

Nevertheless, as far as jurisprudence goes, the question of "prayer behind a sinful imam" was more complex than the pithy language of catechisms would have us believe. In the rest of the section, I discuss how Ottoman Hanafi jurists of Rum allowed room for invoking one Hanafi opinion (prayer behind a sinful imam is permissible) over the other (imam must be a person of probity). I contend that this was a matter of weighing conflicting norms and values inherent in the difference of opinion between Abū Ḥanīfa (d. 15o/767) and Abū Yūsuf (d. 182/798): on the one hand, praying behind a sinful imam was a legally binding norm. Demanding an unwavering moral compass from an imam was conducive to inviting social unrest. On the other hand, failure to hold a "sinful imam" accountable could corrode religious values. In order to demonstrate how the Ottoman jurists assessed the applicability of these two opinions, I focus on two fatwas issued by the chief jurist Ebū's-su'üd with reference to the discussions of Ottoman Rumi Hanafi jurists from the ninth/fifteenth to the eleventh/seventeenth centuries. By doing so, I discuss how the question of prayer behind a sinful imam betrays the dual authority of muftis, be they the chief jurist or provincial muftis. As a legal authority, the mufti declared the legally binding norms to the courts. But, as a religious authority, he explained the moral dimensions of law. This dual phenomenon is also noteworthy for historicizing the normative discourses of Sunni Islam with an eye to distinguish its legal and moral aspects. ${ }^{111}$

The first fatwa centers on a famous hadith that encapsulates the mainstream Sunni position regarding the permissibility of prayer behind a sinful imam. The hadith constitutes the basis of the opinion attributed to Abū Ḥanīfa and urges

109 Ibid. ii, 27o.

110 Krstić, State and religion 72.

111 See Johansen, Die sündige 246-282. 
the congregations to pray behind imams, be they virtuous Muslims or not. ${ }^{112}$ The fatwa answers the question of whether the hadith can legitimately be acted upon:

Question: "Pray behind every virtuous and sinful person." Is this hadith sound? Is it permissible to abide by it?

Answer: Yes. Follow your official. Do not breach and foment civil disturbance because he commits sins. That is what it means. ${ }^{113}$

As evident from the answer, Ebü's-su'ūd does not only confirm that the hadith is applicable, but also explains how his contemporaries should interpret it. "Follow your official," Ebū's-su'ūd notes, to signify a legally binding norm derived from the hadith that deters Muslims from confronting an imam through a refusal to congregate behind him for prayer. The moral condition of imams as state officials (ehl-i berāt $)^{114}$ does not provide a legitimate basis for the congregations abandoning their masjids. Quite to the contrary, this collective act means a "breach" that invites "civil disturbance" in daily life.

In legal terms, Ebū's-su'ūd considers both a sinful and a virtuous Muslim equally suitable to serve as a prayer leader. ${ }^{115}$ By doing so, he censures recourse to unrest as a means of forbidding wrong. At stake is not merely the duty of regular attendance at the five daily prayers and the Friday noon prayer, but also the preservation of stability in everyday life, which are concerns that Ottoman Rumi Hanafi jurists shared before and after Ebü's-su'ūd. From the ninth/fifteenth century, even Bedre'd-din, who was convicted by the Ottoman government as one of the leading figures behind a massive rebellion, invoked the same hadith to convey his opinion that mirrors Ebū's-su'ūd's. ${ }^{116}$ As Bedre'd-dīn puts it, from a moral point of view, a person who commits sins cannot be bothered to observe religious matters (lā yahtammu bi-amr dìnihi); nevertheless, even though it is reprehensible, it is legally permissible to pray behind a sinful

\footnotetext{
112 Wensick, The Muslim creed 220-221; Katz, Prayer 147-148.

113 "Mes'ele: Șallū khalfa kulli barrin wa fäjirin hadisi sahih olup anın ile 'amel câiz olur mu? Elcevab: Câizdir. 'Emîrinize ittiba' edin, fâcirdir diye hulf edip, isâre-i fitne etmen' demektir." See Ebussuud, Şeyhülislam 177.

114 İnalcık, Osmanlılar'da raiyyet rüsûmu 596-597, 598.

115 Based on her discussion of Kemālpaşazāde's fatwas on Sufi rituals in the context of the conversion of 'imārets/zāviyes into mosques, Çiğdem Kafescioğlu's article in this volume shows that if the words and deeds of imams signified unbelief, prayers performed behind imams were considered null and void. By doing so, Kafescioğlu highlights that Kemālpaşazāde's fatwas resonate with Ebū's-su'ūd's.

116 See also Chiwīzāde, al-İthār 176.
} 
imam because of the hadith. ${ }^{117}$ In the eleventh/seventeenth century, Mevkūfătī Mehmed makes a similar case for the permissibility while acknowledging its reprehensibility (emr-i dīnde ihtimāmı olmadığıçūn). He even goes a step further and evokes the topos of historia magistra vitae by invoking an exemplum from a politically volatile period of Umayyad history in order to stress the necessity of peace by congregating behind an imam regardless of his sins. Many of the Prophet Muhammad's Companions and their immediate successors (șahāabe ve täbi ündan çok kimesne) continued to pray behind the notorious governor al-Ḥajjāj bin Yūsuf al-Thaqafĩ (d. 95/714), whom Mevḳūātī describes as the tyrant Hajjajj (Haccāc-ızālim). ${ }^{118}$ Clearly, the act of renouncing the prayer behind sinful imams was understood to have subversive connotations.

Despite the legal opinion that enjoined Muslims to pray behind a sinful imam, we do know that just like judges, ${ }^{119}$ imams could also be dismissed, ${ }^{120}$ although how the Ottoman jurists discussed the practice of dismissals has not been explored. ${ }^{121}$ Ebü's-su'ūd's other fatwa demonstrates how it was possible, if not always achievable, for the congregations to hold a "sinful imam" accountable to the standards of probity, in cases when they had recourse to legitimate means of forbidding wrong:

Question: If the people of a neighborhood say "We are aware that the imam-preacher Zeyd does not refrain from interacting with unrelated women, committing forbidden acts, and lying, but we cannot prove it. We are loath to pray behind him" about the imam-preacher of their mosque, can they have him dismissed?

Answer: Yes, as long as those who are loath to pray are the righteous of the neighborhood. ${ }^{122}$

117 Bedre'd-dīn, al-Tashïl i, 98.

118 Mevḳūfātī Meḥmed, Şerhü̉'l-Mevkūuāàt i i, 8o. See also, Dāmād Efendī, Majmū'a al-anḥur i, 163 .

119 İnalcık, Adâletnâmeler $75^{-79}$, especially 78.

120 Jennings, Limitations of the judicial powers 177-178; Majer, Ulema 111; Beydilli, Osmanlı döneminde imamlar 6-7; Özcan, Osmanlı mahallesi 138-140.

121 This does not mean that there was no distinction between the court-binding norms and religious-ethical norms. See Johansen, Die sündige 246-282. For a recent article that underscores the necessity to incorporate jurisprudential debates into our analyses of court cases, see Aykan, Property between life and death 211-228; See also, Ibid., Rendre la justice à Amid, especially, 162-226.

122 "Mes'ele: Bir câmi'in mahallesi halkı imam hatib olan Zeydin 'nâ-mahrem avret ile mu'âmelesin ve haramdan ve kizbden ictinâb etmediğine bizim ıttılâ'ımız oldu, amma isbâta kâdir değiliz, istikrah ettik iktidâ etmeziz' deseler azl ettirmeğe kâdir olurlar mı? Elcevāb: Olurlar, mahallenin eslehâsı istikrah edicek." See Ebussuud, Şeyhülislam 68. 
Here, the "people of neighborhood" raise the question of prayer behind a sinful imam. Differing from the previous fatwa, civil disturbance is not necessarily a matter of concern as the neighborhood disputes the imam through legal channels. "We are loath to pray behind him," the neighborhood declares and demands dismissal because in their eyes Zeyd fails to live up to the religious and moral codes by "interacting with unrelated women, committing forbidden acts, and lying."

As far as the evidentiary circumstances are concerned, however, the neighborhood faces challenges. ${ }^{123}$ They resort to an expression "we are aware of it, but cannot prove it," whereby they admit the conjectural basis of their allegations. Moreover, their lack of evidence is compounded by the imam's higher status in the social hierarchy and the fact that contemporary sultanic lawbooks (kānūnnāmes) envisioned different punishments for different social strata. The lawbooks stipulated that the discretionary punishment for culpable imams was admonition instead of the usual more severe sanctions. ${ }^{124}$ Against these odds, the neighborhood resorted to witnessing en masse in order to bypass the strict evidentiary requirements. This strategy was "one of the most convincing indicators of the collective competency of the community in the use of the judicial process to advance its own interests," as Boğaç Ergene observes in similar cases where the defendant was an official or a member of the elite. ${ }^{125}$ Ebū's-su'ūd's answer clearly shows the effectiveness of collective witnessing. He rules that the imam could indeed be dismissed "as long as those who are loath to pray are the righteous of the neighborhood." By this caveat, he refers to a court procedure through which social credibility, honesty, and ability of witnesses to testify before the judge was established. ${ }^{126}$

The point Ebū's-su'üd makes is that to say "we are loath to pray behind him" cannot lead to an imam's dismissal if its association with a feeling of dislike is arbitrary. This opinion carried its influence well into the eleventh/ seventeenth century. In other words, while the permissibility of prayer behind a sinful imam was still the norm, the moral opinion that the imam should be a

123 Interestingly, when it comes to the judges, within advice-to-sultans literature, Hans Georg Majer shows that a number of Ottoman authors from Lüṭ̂i Pasha (d. 970/1563) to Șarı Mehmed Pasha (d. 1129/1717) emphasized the necessity to dismiss them after recurring violations rather than one or two complaints or as a result of an investigation based on sound proof. See Majer, Die Kritik an den Ulema 147, 149-150.

124 Akgündüz (ed.), Kanûni devri kanunnâmeleri iv/i, 318; Ibid. vi/ii, 487; Akgündüz (ed.), Selim devri kanunnâmeleri vii/ii, 356 .

125 Ergene, Local court 151.

126 This procedure was called "witness reliability verification" (tezkìye). See Coşgel and Ergene, The economics of Ottoman justice 72-73, 226-231. 
man of probity remained legitimate as long as the demands for dismissals were not arbitrary. For instance, the chief jurist Minkāāizāade Yahyā (d. 1088/1678) was asked:

Question: If some people harbor animosity towards imam Zeyd, but if his state of affairs does not necessitate dismissal in any way, can they have him dismissed by the judge with an appeal "we do not want Zeyd"?

Answer: No. ${ }^{127}$

The fatwa makes it clear that if the reasons do not ring true with any "condition that necessitates dismissal," appeals against an imam are bound to be rejected. As Minkārīzāde Yahyā’s naysay indicates, the chief jurists did not authorize the dismissal of an imam just because the congregation disliked him. In support of his fatwa, Minḳārīzāde cites an authoritative text of the Hanafi school, alFatāwa l-Tätärkhāniya. From this citation, we learn that the fatwa's genealogy goes as far back as one of the three founding scholars of Hanafi school, Abū Yūsuf, and his own discussion of prayer behind a sinful imam. For Abū Yūsuf, the people of a neighborhood cannot render an imam unwanted "unless he is sinful" (illā 'an yakūna fäsiqan), ${ }^{128}$ where a "sinful person" denotes a status that is the exact opposite of a person of probity. ${ }^{129}$ As such, Minkārīzāde's fatwa ultimately hinges on Abū Yūsuf's opinion which not only underscores the moral duty of imams to be persons of probity but also safeguards imams from unjustifiable dismissals by the standard that probity itself imposes. In this respect, Ebū's-su'ūd's two different answers for the question of prayer behind a sinful imam suggests a weighing of opposing Hanafi opinions with an eye to the circumstances of a case, and especially its bearing on community order and morality.

\section{5}

Conclusion

This paper has discussed how the leading Hanafi jurists provided the Ottoman dynasty with a legal and moral idiom to discipline its male Muslim subjects by

127 "Mes'ele: Bir mahallede vāḳi' mescidde imām olan Zeyd'in bir vechile 'azlin icāb ider hāaliyok iken cemā'atden ba ‘̇̀̄ kimesneler Zeyd'e garaż ve ta'așșub idüb hạkkime Zeyd'i istemeziz deyu 'azletdirmeğe kạadir olurlarmı? El-cevāb: Olmazlar." Minḳāī̄āde Yahyā, Fetāvā-yı 'Ațā̉ullāh $7 \mathrm{~b}$.

128 Ibid.

129 Gardet, Fāssk 834. 
enforcing the congregational performance of the five daily prayers. By contextualizing the famous decree on the construction of masjids in Muslim villages with reference to imperial rivalries and religious politics in the long tenth/sixteenth century, the paper highlights the Ottoman reception of two age-old debates that shaped the history of Sunni Islam: the normative value of the five daily congregational prayers and prayer behind a sinful imam. The cases discussed here illustrate that by carefully examining how the Ottoman political and legal authorities inherited and participated in the long-standing jurisprudential questions like these, we can see how they understood the Hanafi and Sunni tradition as well as its relationship to political authority and its increasing aspirations to regulate the moral well-being of the Muslim subjects.

When it comes to the normative value of the five daily congregational prayers, the paper demonstrates that the decree was informed by the decision of the leading jurists and the sultan to promote the coercive function of the state in order to respond to the challenges of religious pluralism and legitimacy which were especially intensified by imperial rivalries after the turn of the tenth/sixteenth century. Central to the imperial policy of coercing the attendance was the question of prayer behind a sinful imam. As opposed to the question of whether the five daily congregational prayers constituted a duty for the adult male Muslims to observe and for the sultan to enforce, where the jurists opted for a more top-down, interventionist solution, prayer behind a sinful imam remained a thorny question that was receptive to the moral reservations arising from the Muslim congregations. On the one hand, this pressure from "below" was part of a long-established dynamic of governance. One the other, however, this was the time of evolving Sunni sensibilities among the common Muslims due to attempts to increase their understanding of what constitutes correct practice and belief through preaching and closer attention to public expressions of piety, especially in the cities. The paper, thus, suggests that Ottoman Sunnitization was a multidirectional process that negotiated various legal and moral registers of Islam that were themselves constantly evolving in pace with the developing Ottoman polity.

\section{Acknowledgments}

I would like to thank the editors Tijana Krstić and Derin Terzioğlu, as well as Yavuz Aykan, Aslıhan Gürbüzel, Cemal Kafadar, Ana Sekulić, and the anonymous reviewers for their feedback. The research for this article was supported by the оттосONFESSION project and the Gerda Henkel Foundation. All translations are mine unless otherwise stated. 


\section{Bibliography}

\section{Primary Sources}

Ahterî, Ahterî-yi kebir, eds. Y. Sancak and A. Kırkkılıç, Ankara 2017.

Akgündüz, A. (ed.), Kanunî devri kanunnâmeleri: Merkezî ve umumî kanunnâmeler, iv, pt. i, Istanbul 199o.

Akgündüz, A. (ed.), Kanunî devri kanunnâmeleri: Eyalet kanunnameleri, vi, pt. ii, Istanbul 1990.

Akgündüz, A. (ed.), Selim devri kanunnâmeleri, vii, pt. ii, Istanbul 1990.

al-Bābartī, A.D.M., al-'Ināya sharh al-Hidāya, ed. 'A.B. Maḥrūs, i, Beirut 2007.

Birgivī Meḥmed, Jalā’ al-qulūb, ed. ‘Ā.S. al-Zībārī, Beirut 1995.

Çatalcalı Ali, Açıklamalı Osmanlı fetvâları: Fetâvâ-yı Ali Efendi (1674-1686), ed. H.N.

Demirtaş, i, Istanbul 2014.

Çavuşoğlu, M., Zâtî̀nin letâyifi, in Türk dilive edebiyatı dergisi 18 (1970), 25-51.

Chiwīzāde, al-İthār li-hal al-mukhtār, ed. İ. Qablan, i, Istanbul 2014.

Dāmād Efendī, Majmū'a al-' anḥur fı̀ sharh Multaqā al-abḥur, Beirut 2016.

Ebū's-su'ūd, Fetāvā-yı Ebū's-su'ūd, Millet Kütüphanesi, Ms Ali Emiri sRY 8o.

Ebussuûd, Şeyhülislam Ebussuûd Efendifetvaları ısığında ı6. asır Türkhayatı, ed. E. Düzdağ, Istanbul 1983 .

Ebussuûd, Ma'rûzât: Şeyhülislam Ebussuûd Efendi, ed. P. Düzenli, Istanbul 2013.

Ebū Su'ūd, Zur Anwendung des Islamischen Rechts im 16. Jahrhundert: die "juristischen Darlegungen" (ma'rūì̄āt) des Schejch ül-Islam Ebū Su'ūd (gest. 1574) herausgegeben, übersetzt und untersucht, ed. P. Horster, Stuttgart 1935.

Es`ad Efendi, Fetāvā-yı Müntehab, Süleymaniye Kütüphanesi, Ms Kasidecizade 277.

Feyzullah Efendi, Fetâvâ-yı Feyziyye, ed. S. Kaya, Istanbul 2010.

al-Halabī, I., Ghunyat al-mutamallī fì sharh Munyat al-muṣallī, Lahore 1979.

Ibn Abī al-'Izz, al-Tanbīh 'alā mushkilāt al-Hidāya, ed. 'A.B.M. Shākir, Cairo 2003. Iftikhār al-Dīn, Khulāṣat al-fatāwā, Princeton University Library, Ms Garrett 12 Yq. İnalcık, H., Adâletnâmeler, in Belgeler: Türk tarih belgeleri dergisi 2 (1965), 49-145. al-Jurjānī, Kitāb al-tā'rīfāt, ed, M.'A. al-Mar'ashlī, Beirut 2003.

İbn Kemāl, Fetāvā, Süleymaniye Kütüphanesi, Ms Darülmesnevi 118.

İbn Kemāl, Fetāōa, Süleymaniye Kütüphanesi, Ms Hacı Mahmud Efendi 1224.

[İbn Kemal], Şeyhülislâm İbn Kemal'in fetvaları ışı̆̆ında Kanûnî devrinde Osmanlıda hukukî hayat: Mes'eleler ve çözümleri (Fetâvâ-yı ibn Kemal), ed. A. İnanır, Istanbul 2011.

İbn Melek, Sharh majma al-bahrayn, Ankara Üniversitesi, İlahiyat Fakültesi Kütüphanesi, Ms 674.

Lāmi'ī Çelebī, Letā’if-i Lāmi ‘̄, İstanbul Üniversitesi Nadir Eserler Kütüphanesi, MS T3814.

Maḥmūd ibn Qāḍ̄i Simāwna [Bedre'd-dīn], al-Tashīl sharh laṭāî̉ al-'ishārāt fì bayān almasāil al-khilāfı̀āt fì al-fiqh al-Hanafi, ed. I.M. Muḥammad, i, Beirut 2015. 
Mevkūfātī Meḥmed, Şerḥü'l-mevḳūfātī, i, Istanbul 1302/1885.

Minḳārīzāde Yahyā, Fetāo $\bar{a}-y \iota$ 'Ațāullāh, University of Michigan, Ms 68.

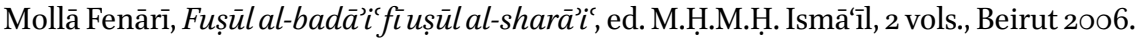
Mollā Hüsrev, Mirqāt al-wușūl 'ilā 'ilm al-uṣūl fì uṣūl al-fiqh, ed. İ. Kablān, Beirut 2012.

Mollā Hüsrev, Durar al-ḥukkām fì sharh ghurar al-ậkām, 2 vols., Cairo 1291/1872.

Sa'dī Chalabì, Ḥāshīya Sa'dì Chalabì 'alā al-Hidāya, in Sharh fatḥ al-qadīr, ed. Mustafa al-Bābī al-Ḥalabī, Egypt 1970.

Ṭāşköprüzāde, Miftāḥ al-sacāda wa-miṣbāḥ al-siyāda fı maw dūuāt al-ulūm, ed. 'Alī Daḥrūjin, Beirut 1998.

Tietze, A., The poet as critique of society: A 16th century Ottoman poem, in Turcica 9 (1977), 120-16o.

Yenişehirli Abdullah, Behcetü'l-fetâvâ, eds. S. Kaya et al., Istanbul 2012.

Zekerīyāzāde Yaḥyā, Fetāvā-yı Yahyyā Çelebì, Gazi Husrev Beg Library (Sarajevo), MS 3783 .

\section{Secondary Sources}

Akyüz, V., İkāmet, in TDV, xxii, 16-17.

Atçl, A., Scholars and sultans in the early modern Ottoman Empire, Cambridge 2017.

Atçll, A., Mobility of scholars and formation of a self-sustaining scholarly system in the lands of Rūm during the fifteenth century, in Peacock, A.C.S. and S.N. Yıldız (eds.), Islamic literature and intellectual life in fourteenth- and fifteenth-century Anatolia, Würzburg 2016, 315-332.

Aykan, Y., Property between life and death: A legal debate over the property of a missing person (gâib) in eighteenth-century Ottoman Amid, in Turcica 5o (2019), 211-228.

Aykan, Y., A legal concept in motion: The "spreader of corruption" (sā' Qarakhanid to Ottoman jurisprudence, in Islamic law and society 26 (2019), 252-271.

Aykan, Y., Rendre la justice à Amid: Procédures, acteurs et doctrines dans le contexte Ottoman du XVIII ${ }^{\text {ème }}$ siècle, Leiden 2016.

Ayoub, S. "The sulțān says": State authority in the late Hanafī tradition, in Islamic law and society 23 (2016), 239-278.

Balivet, M., Islam mystique et révolution armée dans les Balkans Ottomans: vie du Cheikh Bedreddîn le "Hallâj des Turcs" (1358/59-1416), Istanbul 1995.

Baltacıoğlu-Brammer, A., The formation of Kızılbaş communities in Anatolia and Ottoman responses, 1450s-163os, in International Journal of Turkish Studies 20/1-2 (2014): 21-48.

Beydilli, K., Osmanlı döneminde imamlarve bir imamın günlüğü, Istanbul 2001.

Binbaş, İ.E., Intellectual networks in Timurid Iran: Sharaf al-Dīn 'Alī Yazdī and the Islamicate republic of letters, Cambridge 2016.

Burak, G., The second formation of Islamic law: The Hanafi legal school in the Ottoman Empire, Cambridge 2015 . 
Burak, G., Faith, law and empire in the Ottoman "age of confessionalization" (fifteenthseventeenth centuries): The case of "renewal of faith," in Mediterranean historical review 28 (2013), 1-23.

Calder, N., Friday prayer and the juristic theory of government: Sarakhsī, Shīrāzī, Māwardī, in BSOAS 49 (1986), 35-47.

Canbakal, H., Some questions on the legal identity of neighborhoods in the Ottoman Empire, in Anatolia Moderna 10 (2004), 131-138.

Coşgel M. and B. Ergene, The economics of Ottoman justice: Settlement and trial in the sharia court, Cambridge 2016.

Ergenç, Ö., Osmanlı şehrindeki "mahalle"nin işlev ve nitelikleri üzerine, in Jos, iv (1984), 69-78

Ergene, B., Local court, provincial society, and justice in the Ottoman Empire: Legal practice and dispute resolution in Çankırı and Kastamonu (1652-1744) (SILS 17), Leiden 2003.

Fahd, T., Shicār, in $E I^{2}$, ix, 424.

Fleischer, C.H., Learning and sovereignty, in Necipoğlu G., C. Kafadar, and C.H. Fleischer (eds.), Treasures of the palace: An inventory of the Ottoman palace library (1502/31503/4), Leiden and Boston 2019, 155-160.

Fleischer, C.H., The Lawgiver as Messiah: The making of the imperial image in the reign of Süleyman, in G. Veinstein (ed.), Soliman le Magnifique et son temps: Actes du colloque de Paris. Galeries nationales du Grand Palais, 7-10 Mars 199o, Paris 1992, 159-177.

Fleischer, C.H., From Şeyhzade Korkud to Mustafa Âli: Cultural origins of the Ottoman nasihatname, in Lowry, H.W. and R.S. Hattox (eds.), Third congress on the social and economic history of Turkey, Istanbul 1990, 67-77.

Flemming, B., Sāḥib-ḳıān und Mahdī: Türkische Endzeiterwartungen im ersten Jahrzehnt der Regierung Süleymāns, in G. Veinstein (ed.), Soliman le Magnifique et son temps: Actes du colloque de Paris. Galeries nationales du Grand Palais, 7-10 Mars 199o, Paris 1992, 43-62.

Gardet, L., Fāsılk, in $E I^{2}$, ii, 833-834.

Greene, M., The Edinburgh history of the Greeks, 1453 to 1768: The Ottoman Empire, Edinburgh 2015.

Has, Ş.S., A study of Ibrāhīm al-Ḥalabī with special reference to the Multaqā, $\mathrm{PhD}$ diss., University of Edinburgh 1981.

Imber, C., Süleyman as caliph of the muslims: Ebû's-Su'ûd's formulation of Ottoman dynastic ideology, in G. Veinstein (ed.), Soliman le Magnifique et son temps: Actes du colloque de Paris. Galeries nationales du Grand Palais, 7-10 Mars 1990, Paris 1992, 179184.

İnalcık, H., Osmanlılar'da raiyyet rüsûmu, in Belleten 23 (1959), 575-610.

İnanır, A., İbn Ebi'l-İzz'in “İttibâ" adlı risalesi bağlamında Ebu Hanife ve Hanefi mezhebi 
örneğinde taklide dair görüşleri, in Gaziosmanpaşa üniversitesi ilahiyat fakültesi dergisi 1 (2013), 225-26o.

Jennings, R.C.J., Limitations of the judicial powers of the kadi in the 17th C. Ottoman Kayseri, in SI 50 (1979), 151-184.

Johansen, B., Zum Prozessrecht der 'uqūbāt, in Contingency in a sacred law: Legal and ethical norms in the Muslim figh, Leiden 1999, 421-433.

Johansen, B., Die Sündige, gesunde Amme. Moral und gesetzliche Bestimmung (hukm) im islamischen Recht, in WI 28 (1998) 262-284.

Johansen, B., The all-embracing town and its mosques: al-Miṣr al-ğāmi', in Revue de l'Occident Musulman et de la Méditerranée 32 (1981-1982), 139-162.

Juynboll, T.W., Ikạama, in $E I^{2}$, iii, 1057 .

Karakaya-Stump, A., The Kizilbash-Alevis in Ottoman Anatolia: Sufism, politics, and community, Edinburgh 2020.

Karamustafa, A.T., Islamic dìn as an alternative to western models of "religion," in R. King (ed.), Religion, theory, critique: Classic and contemporary approaches and methodologies, New York 2017, 163-171.

Karataş, H., Onbeşinci yüzyılda Karamânî ulemâ ve meşayıh ilişki ağları üzerine tesbitler, in Ö.M. Alper and M. Arıcı (eds.), Osmanlida ilim ve fikir dünyası: İstanbul'un fethinden Süleymaniye medreselerinin kuruluşuna kadar, Istanbul 2015, 283-298.

Kastritsis, D.J., The sons of Bayezid: Empire building and representation in the Ottoman civil war of 1402-1413, Leiden 2017.

Katz, M.H., 'Azīma and rukhșa, in $E I^{3}$, iii, 188-19o.

Katz, M.H., Prayer in Islamic thought and practice, Cambridge 2013.

Katz, M.H., The "corruption of the times" and the mutability of the Shari'a, in Cardozo law review 28 (2006), 171-185.

Kıvrım, Osmanlı Mahallesinde Gündelik Hayat (17. Yüzyılda Gaziantep Örneği), in Gaziantep Üniversitesi Sosyal Bilimler Dergisi 8/1 (2009), 231-255.

Kim, S., The last of an age: The making and unmaking of a sixteenth-century Ottoman poet, London 2018.

Krstić, T., State and religion, "Sunnitization" and "confessionalism" in Süleyman's time, in P. Fodor (ed.), The battle for Central Europe: The siege of Szigetvár and the death of Süleyman the Magnificent and Nicholas Zrínyi (1566), Leiden 2019, 65-91.

Krstić, T., Contested conversion to Islam: Narratives of religious change in the early modern Ottoman Empire, Palo Alto 2011.

Majer, H.G., Ulema und "kleinere Religionsdiener" in einem Defter der Jahre vor 1683, in H.G. Majer (ed.), Osmanistische Studien zur Wirtschafts- und Sozialgeschichte: in memoriam Vančo Boškov, Wiesbaden 1986, 104-119.

Majer, H.G., Die Kritik an den Ulema in den Osmanischen Politischen Traktaten des 16. -18. Jahrhunderts, in O. Okyar and H. Ínalcık (eds.), Social and economic history of Turkey (1071-1920), Ankara 1980, 147-153. 
Mandaville, J.E., Usurious piety: The cash waqf controversy in the Ottoman Empire, in IJMES 10 (1979), 280-308.

Necipoğlu, G., The age of Sinan: Architectural culture in the Ottoman Empire, Princeton 2005.

Necipoğlu, G., Süleyman the Magnificent and the representation of power in the context of Ottoman-Hapsburg-Papal rivalry, in The art bulletin 71 (1989), 401-427.

Ocak, A.Y., Osmanlı toplumunda zındıklar ve mülhidler (15.-17. yüzyıllar), Istanbul 1998.

Ocak, A.Y., Idéologie officielle et réaction populaire: un aperçu général sur les mouvements et les courants socio-religieux à l'époque de Soliman le Magnifique, in G. Veinstein (ed.), Soliman le Magnifique et son temps: Actes du colloque de Paris. Galeries nationales du Grand Palais, 7-10 Mars 1990, Paris 1992, 185-92.

Ökten, E., Scholars and mobility: A preliminary assessment from the perspective of alShaqāyiq al-nu'māniyya, in Jos 41 (2013), 55-70.

Özcan, T., Osmanlı mahallesi: Sosyal kontrol ve kefalet sistemi, in Marife 1 (2001), 129151.

Özen, Ş., Molla Hüsrev'in velâ meselesi ile ilgili görüşünün Osmanlı ilim muhitindeki yansımaları, in T. Yücedoğru, O.Ş. Koloğlu, U.M. Kılavuz and K. Gömbeyaz (eds.), Uluslararası Molla Hüsrev sempozyumu (18-20 Kasım 2011 Bursa): Bildiriler, Bursa 2013, 321-394.

Özervarlı, S., Şiâr, in $T D V$, xxix, 123-124.

Peacock, A.C.S. and S.N. Yıldız, Introduction: Literature, language and history in late medieval Anatolia, in A.C.S. Peacock and S.N. Yıldız (eds.), Islamic literature and intellectual life in fourteenth- and fifteenth-century Anatolia, Würzburg 2016, 1942.

Reinhart, A.K., "Like the difference between heaven and earth:" Hanafĩ and Shāfi'i discussions on wäjib and fard, in B.G. Weiss (ed.), Studies in Islamic legal theory, Leiden 2002, 205-234.

Reinhart, A.K., When women went to mosques: al-Aydini on the duration of assessments, in M.K. Masud, B. Messick and D.S. Powers (eds.) Islamic legal interpretation: Muftis and their fatwas, Cambridge 1996, 116-128.

Repp, R.C., The müfti of Istanbul: A study in the development of the Ottoman learned hierarchy, London 1986.

Sohrweide, H., Der Sieg der Safaviden und seine Rückwirkungen auf die Schiiten Anatoliens, in Der Islam 41 (1965), 95-223.

Stewart, D., Polemics and patronage in Safavid Iran: The debate on Friday prayer during the reign of Shah Tahmasb, in BSOAS 7 (2009), 425-457.

Tamdoğan-Abel, I., Les relations de voisinage d'après les livres de morale Ottomans (XVIe-XVIIIe siècles), in Anatolia Moderna 10 (2004), 167-179.

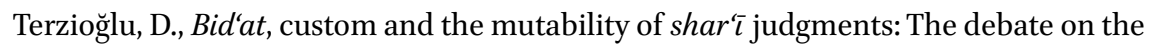
congregational performance of supererogatory prayers in the seventeenth-century 
Ottoman Empire, in A. Somel and S. Kenan (eds.), Dimensions of transformation in the Ottoman world: Essays in honor of Metin Kunt, Leiden (forthcoming).

Terzioğlu, D., How to conceptualize Ottoman Sunnitization: A historiographical discussion, in Turcica 44 (2012-2013), 301-338.

Terzioğlu, D., Where 'ilm-i hâal meets catechism: Islamic manuals of religious instruction in the Ottoman Empire in the age of confessionalization, in Past and present 220 (2013), 79-114.

Tsugitaka, S., State and rural society in Medieval Islam: Sultans, muqta's and fallahun (IHC 17), Leiden 1997.

Wensinck, A.J., The Muslim creed:Its genesis and historical development, New Delhi 1979.

Yıldırım, R., Turcomans between two empires: The origins of the Qizilbash identity in Anatolia (1447-1514), PhD diss., Bilkent University, 2008.

Yıldız, S.N., From Cairo to Ayasuluk: Hacı Paşa and the transmission of Islamic learning to Western Anatolia in the late fourteenth century, in JIS 25 (2014), 263-297.

Yılmaz, F., XVI. yüzyll Osmanlı toplumunda mahremiyetin sınırlarına dair, in Toplum ve Bilim 83 (1999-2000), 92-110.

Yılmaz, H., Caliphate redefined: The mystical turn in Ottoman political thought, Princeton 2018. 